\title{
Intravenous Transplantation of BMP2- Transduced Endothelial Progenitor Cells Attenuates Lipopolysaccharide-Induced Acute Lung Injury in Rats
}

\author{
Xiuru Yin Zuodi Liang Yue Yun Ling Pei \\ Department of Anesthesiology, the First Affiliated Hospital of China Medical University, \\ Shenyang, Liaoning, China
}

\section{Key Words}

Endothelial progenitor cells $\bullet$ Bone morphogenetic protein $\bullet$ Lipopolysaccharide $\cdot$ Acute lung injury • Gene therapy

\begin{abstract}
Background/Aims: Acute lung injury (ALI) and its aggressive stage, acute respiratory distress syndrome (ARDS), are characterized by diffuse damage and increased permeability of the endothelial barrier, leading to alveolar infiltrates and interstitial edema. Enhancing endothelial integrity represents a novel therapeutic strategy for ALI/ARDS. Endothelial progenitor cells (EPCs) have been reported to participate in endothelial repair of ALI and also serve as a tool for gene therapy. Further, bone morphogenetic protein 2 (BMP2) is an essential signaling molecule that regulates the fate of different cell types. The aim of our study is to explore whether bone marrow-derived EPCs transduced with lentiviral-mediated BMP2 gene might benefit lipopolysaccharide (LPS)-induced ALI in a rat model. Methods: Rats were divided randomly into five groups. The sham group was given normal saline via the trachea and right jugular vein. The other four groups underwent intratracheal-LPS-induced ALI followed after 30 min by treatment with either normal saline, EPCs, EPCs transduced with empty lentiviral vector (EPCs-null), or EPCs transduced with BMP2 (EPCs-BMP2) via the right jugular vein. Results: We found that the lung injury score, oxygenation, and inflammatory response were significantly ameliorated in the three EPC-treated groups (EPCs, EPCs-null, and EPCs-BMP2). In addition, EPCs-BMP2 further improved endothelium repair and capillary permeability, causing markedly reduced wet-to-dry lung-weight ratio and BALF protein content, and increased levels of BMP2 protein, BMP2 mRNA, and eNOS protein in lung tissues. Conclusion: Transplantation of BMP2-transduced EPCs effectively attenuates edema and protein exudation compared with EPCs alone in LPS-induced ALI via enhanced expression of BMP2 and eNOS.
\end{abstract}

Ling Pei

KARGER 125
Department of Anesthesiology, the First Affiliated Hospital of China Medical University Nanjing North Street 155, Heping District, Shenyang City, Liaoning Province, Postal code: 110001 (P. R. China), Tel. +8602483282435, E-Mail lingpei49@vip.sina.com 


\section{Cellular Physiology Cell Physiol Biochem 2015;35:2149-2158 \begin{tabular}{ll|l} 
aOI: 10.1159/000374020 & $\begin{array}{l}\text { O 2015 S. Karger AG, Basel } \\
\text { www.karger.com/cpb }\end{array}$ \\
\hline
\end{tabular} \\ Yin et al.: BMP2-Transduced Endothelial Progenitor Cells Attenuate Acute Lung Injury}

\section{Introduction}

Acute lung injury (ALI) and acute respiratory distress syndrome (ARDS) are devastating clinical disorders with high morbidity and mortality in intensive care units [1]. Despite recent advances in supportive care and pharmacologic treatments, ALI/ARDS still lacks specific therapies. The physiological hallmark of ALI/ARDS is diffuse endothelial injury characterized by persistently increased lung microvascular permeability, resulting in the accumulation of protein-rich edema fluid in the alveolar spaces [2]. Regeneration of the pulmonary endothelium has thus emerged as a promising therapeutic target for ALI/ARDS.

Endothelial progenitor cells (EPCs) were first discovered by Asahara et al in 1997 [3], and their potential regenerative and immunomodulatory capabilities in oleic acidor lipopolysaccharide (LPS)-induced ALI have since been extensively documented [48]. Transplanted EPCs can differentiate into endothelial cells, preserve the function and integrity of the alveolar-capillary barrier, and adjust cytokine secretion to modulate the immune response $[9,10]$. EPCs may also serve as a vehicle for specific genes to strengthen the therapeutic effect. The combination of EPCs and gene therapy has proven successful in the treatment of experimental limb ischemia [11-14], carotid artery injury [15, 16], and pulmonary hypertension $[17,18]$.

Bone morphogenetic protein 2 (BMP2) is a member of the bone morphogenetic proteins, belonging to the transforming growth factor- $\beta$ superfamily. Previous studies have demonstrated a crucial role for BMP2 in maintaining vascular homeostasis to promote angiogenesis [19] and induce chemotaxis [20] of stem cells. BMP2 signaling has been shown to be involved in the survival [21] and barrier function [22] of endothelial cells. Thus, BMP2 may have a great potential to be utilized in gene therapy.

So far there is no report on synergistic effects of EPCs and BMP2 in the treatment of ALI. This study aimed to evaluate the therapeutic effect and underlying mechanisms of BMP2transduced EPCs in an LPS-induced ALI model in rats.

\section{Materials and Methods}

\section{Experimental animals}

Adult male Sprague-Dawley rats (8 weeks old, 220-250 g, $\mathrm{n}=40$ ) were obtained from the Laboratory Animal Center of China Medical University (Shenyang, China) and raised under pathogen-free conditions. All procedures were performed in accordance with the guidelines for the ethical use of laboratory animals and were approved by the Animal Care and Use Committee of China Medical University.

Isolation and culture of bone marrow-derived EPCs

As described previously with minor modifications [23], bone marrow was obtained under sterile conditions from the femurs and tibias of rats anesthetized with intraperitoneal $10 \%$ chloral hydrate $(0.3$ $\mathrm{ml} / 100 \mathrm{~g}$ ). Mononuclear cells were fractionated by density gradient centrifugation with Histopaque-1083 (Sigma, San Louis, MO), according to the manufacturer's protocol, and seeded on human-fibronectin-coated culture dishes in endothelial culture medium composed of EGM-2MV Single Quots (Lonza, Switzerland). The cells were incubated at $37^{\circ} \mathrm{C}$ in $5 \% \mathrm{CO}_{2}$ and fed with EGM-2MV every $48 \mathrm{~h}$. Non-adherent cells were removed and adherent cells were harvested by trypsinization after three passages (known as late EPCs) and used for analysis or gene transfer.

\section{Characterization of EPCs}

EPCs isolated from rats were characterized on the basis of their morphology, acetyl-low density lipoprotein (ac-LDL) uptake and Ulex europaeus agglutin-1(UEA-1) binding, and by phenotypic examination [24]. In brief, cells were incubated with DiI labeled ac-LDL (10 $\mu \mathrm{g} / \mathrm{ml}$; Invitrogen, OR) for $4 \mathrm{~h}$ at $37^{\circ} \mathrm{C}$, fixed with $2 \%$ paraformaldehyde for $10 \mathrm{~min}$, and then incubated with fluorescein isothiocyanate (FITC)-labeled UEA-1 ( $5 \mu \mathrm{g} / \mathrm{ml}$; Sigma) for $1 \mathrm{~h}$. Flow cytometry of the cell surface antigen markers CD31, CD34, Flk-1, CD45 and CD133 was performed after incubation with the appropriate concentration of FITC- or phycoerythrin- 


\section{Cellular Physiology Cell Physiol Biochem 2015;35:2149-2158

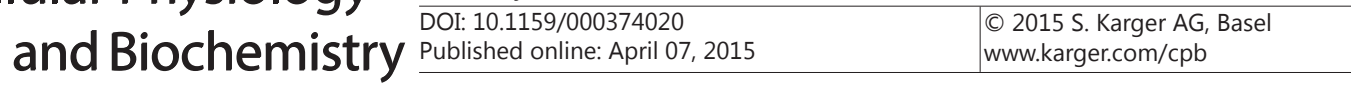 \\ Yin et al.: BMP2-Transduced Endothelial Progenitor Cells Attenuate Acute Lung Injury}

labeled antibody or corresponding IgG isotype control (Santa Cruz, CA) for $30 \mathrm{~min}$ at $4^{\circ} \mathrm{C}$. Cells with the appropriate morphology and phenotype that were positive for both DiI-ac-LDL and FITC-UEA-1 were considered to be EPCs.

\section{Lentivirus-enhanced green fluorescent protein-BMP2 gene transfer}

The lentiviral BMP2 gene vector was constructed by Shanghai GenePharma Co. Ltd. The vector contained the fluorescent cell tracker enhanced green fluorescent protein (eGFP), which was used to determine the transduction efficiency and track the location of the EPCs in the injured lung tissues. The optimal virus concentration for gene transfer was established by testing a range of multiplicities of infection (MOIs), according to the manufacturer's instructions. After these preliminary experiments, EPCs were transduced with lentivirus-eGFP vectors with or without BMP2 at a MOI of 100 in 6-well culture plates at $5 \times 10^{4}$ cells per well. The transduction efficiency at day 7 was calculated as the relative percentage of eGFPexpressing cells, using fluorescence microscopy. The cells were subsequently used for transplantation.

\section{Rat model of ALI and transplantation of EPCS}

Forty rats were divided randomly and evenly in to five groups. All the rats were anesthetized as described above, and orally intubated with a sterile plastic catheter. The sham group was given $0.3 \mathrm{ml}$ normal saline intratracheally and $1 \mathrm{ml}$ normal saline via the right jugular vein. ALI was induced by intratracheal instillation of LPS (Escherichia coli LPS, ET055:B5, Sigma) $10 \mathrm{mg} / \mathrm{kg}$ dissolved in $0.3 \mathrm{ml}$ normal saline. Following LPS challenge for $30 \mathrm{~min}$, saline, EPCs, EPCs transduced with lentivirus-eGFP empty vector (EPCs-null), or EPCs transduced with lentivirus-eGFP-BMP2 gene (EPCs-BMP2) (approximately $2 \times 10^{6}$ cells in a total volume of 1 $\mathrm{ml}$ normal saline) were slowly infused via the right jugular vein. At $72 \mathrm{~h}$ after transplantation, all rats were sacrificed and arterial blood, bronchoalveolar lavage fluid (BALF), and lung tissues were collected ( $\mathrm{n}=8$ in each group).

\section{Pathological examination of lung tissues}

The right lower lung lobes were immersed in 4\% paraformaldehyde and fixed for $24 \mathrm{~h}$. Sections were embedded in paraffin, processed through alcohols, stained with hematoxylin-eosin and examined and photographed under a light microscope. Two independent pathologists blindly scored the lung injury by alveolar congestion, hemorrhage, infiltration of inflammatory cells, and thickness of the alveolar wall into five grades: $0=$ no injury; $1=$ slight injury (0-25\%); $2=$ moderate injury (25-50\%); $3=$ severe injury (50-75\%); $4=$ extreme injury (75-100\%). The total injury score was the sum scores of each item.

\section{Arterial blood gas analysis}

Arterial blood samples were collected and oxygen pressure $\left(\mathrm{PaO}_{2}\right)$ and saturation $\left(\mathrm{SaO}_{2}\right)$ were determined automatically using a blood-gas analyzer (GEM Premier3000, MA).

\section{Lung water content measurement}

Fresh right upper lung lobes were excised and weighed immediately (designated as $\mathrm{W}$ ). The tissues were then dried at $80^{\circ} \mathrm{C}$ for $12 \mathrm{~h}$ in an oven and reweighed (designated as $\mathrm{D}$ ). The wet-to-dry lung-weight ratio was calculated as $\mathrm{W} / \mathrm{D}$.

\section{Determination of BALF protein content}

The right main bronchus was tied at the hilum with string. Lavage was performed by intratracheal injection of $5 \mathrm{ml}$ normal saline followed by three gentle aspirations after $30 \mathrm{~s}$. Recovered fluid was pooled and centrifuged at $2000 \mathrm{rpm}$ for $10 \mathrm{~min}$ at $4^{\circ} \mathrm{C}$. Supernatants were removed and stored at $-80^{\circ} \mathrm{C}$. The total BALF protein content was quantified using the bicinchoninic acid (BCA) method.

Serum tumor necrosis factor- $\alpha$ and interleukin-10 measurements

Serum levels of tumor necrosis factor- $\alpha$ (TNF- $\alpha$ ) and interleukin-10 (IL-10) were measured using enzyme-linked immunosorbent assay kits (R\&D, MN), according to the manufacturer's protocol. Optical density values were compared with a standard curve, and the absorbance was measured at $450 \mathrm{~nm}$ using a microplate reader. 


\section{Cellular Physiology Cell Physiol Biochem 2015;35:2149-2158

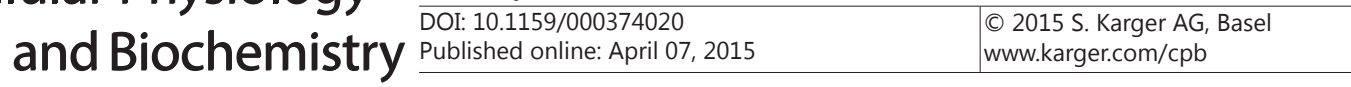

Western blot analysis of BMP2 and endothelial nitric oxide synthase proteins

Soluble protein extracts were isolated from the residual right lung tissues. Protein concentrations were determined by BCA assay. Equal amounts of protein were separated by sodium dodecyl sulfatepolyacrylamide gel electrophoresis and transferred onto polyvinylidene fluoride membranes. Membranes were then blocked with 5\% nonfat dried milk for $2 \mathrm{~h}$, incubated with primary antibodies to BMP2, endothelial nitric oxide synthase (eNOS) (Santa Cruz) and $\beta$-actin overnight at $4^{\circ} \mathrm{C}$, then reacted with horseradish peroxidase-conjugated secondary antibody (Santa Cruz) for $1 \mathrm{~h}$. Blots were washed three times in TBS-Tween after each incubation. Bands were visualized using the enhanced chemiluminescence system and protein levels were quantified using ImageJ software.

Quantitative real-time polymerase chain reaction for BMP2 $m R N A$

Total RNA was extracted from frozen lung tissues with Trizol reagent (Takara, China) and reverse transcribed into cDNA. Quantitative real-time polymerase chain reaction (PCR) was performed using SYBR Green I on an ABI 7500 Real-Time PCR System in a $25 \mu \mathrm{l}$ reaction mixture, using $\beta$-actin as an internal control. The primer sequences were designed as follows: BMP2 forward, $5^{\prime}$-CCCACTTGGAGGAGAAACAA- $3^{\prime}$, reverse, 3'-TAAGGGGCAGGAGGAGAGTT-5'; $\beta$-actin forward, $5^{\prime}$-TGGAATCCTGTGGCATCCATGAAAC-3', reverse, 3'-AAAACGCAGCTCAGTAACAGTCCG-5'. Relative BMP2 mRNA expression levels were calculated using the $\mathrm{Ct}$ method as $2^{-\Delta \Delta \mathrm{Ct}}$ where $\Delta \Delta \mathrm{Ct}=\Delta \mathrm{Ct}($ injury group) $-\Delta \mathrm{Ct}($ sham group) and $\Delta \mathrm{Ct}=\mathrm{Ct}(\mathrm{BMP} 2)-\mathrm{Ct}($ actin) .

\section{Statistical analysis}

All data were presented as mean \pm SD. Statistical analysis was performed using SPSS 19.0 statistical software. Results were assessed by one-way ANOVA followed by Bonferroni test for multiple comparisons, or by Kruskal-Wallis test on ranks. Values of $\mathrm{P}<0.05$ were considered statistically significant.

\section{Results}

\section{Characterization of EPCs}

Monolayer colonies with a cobblestone appearance were observed 1 week later (Fig. 1A). Cells exhibiting red fluorescence were defined as ac-LDL-positive, and those exhibiting green fluorescence as UEA-1-positive, using fluorescence confocal microscopy (Figs. 1B-D). The cell phenotype at the third passage was CD $31^{+} \mathrm{CD} 34^{+} \mathrm{Flk}-1^{+} \mathrm{CD} 45^{-} \mathrm{CD} 133^{-}$, determined by flow cytometry (Fig. 1E). Cells with this morphology and phenotype and exhibiting doublepositive fluorescent staining were identified as late EPCs.

BMP2 transduction efficiency in EPCs

Most cells (>90\%) showed green fluorescence and grew well 7 days after BMP2 transduction (Figs. 1F-H).

\section{Degrees of acute lung injury}

There was no obvious damage to the lung tissues in the sham group (Fig. 2A). In the lung-injury group treated with saline, hematoxylin-eosin staining revealed typical ALI pathological traits including alveolar congestion, hemorrhage, infiltration of inflammatory cells, and thickness of the alveolar wall or formation of hyaline membrane (Fig. 2B). Injured lung tissues treated with EPCs, EPCs-null, and EPCs-BMP2 showed dramatically reduced lesions (Figs. 2C-E) and lower injury score (Fig. 2F), compared with the saline-treated injury group $(\mathrm{P}<0.01)$.

\section{Improvement of lung oxygenation}

After LPS injection, $\mathrm{PaO}_{2}$ and $\mathrm{SaO}_{2}$ were significantly reduced in rats treated with saline but significantly increased with the transplantation of EPCs, EPCs-null, and EPCs-BMP2 $(\mathrm{P}<0.05$, Figs. 3A, B).

Reduction of wet-to-dry lung-weight ratio, and BALF protein content

We determined the wet-to-dry lung-weight ratio and BALF protein content, as markers of microvascular permeability, to assess the severity of lung edema and protein exudation. 

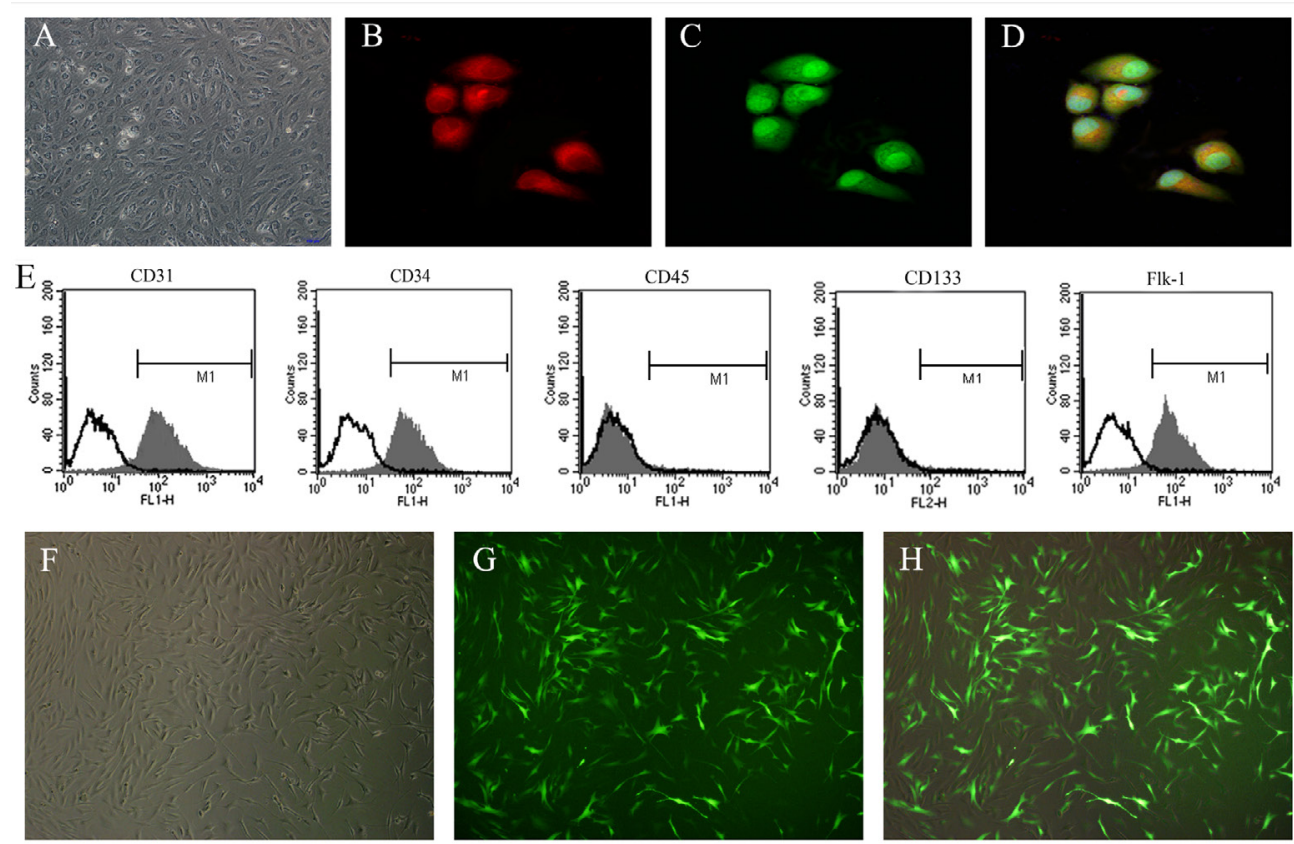

Fig. 1. Characterization of EPCs and BMP2 transduction efficiency. Monolayer colonies with a cobblestone appearance formed 1 week later (A), Bar $=100 \mu \mathrm{m}$. The cells were positive for DiI-acLDL (B, red fluorescence) and FITC-UEA-1 (C, green fluorescence), overlaying to result in micrograph (D), Bar $=200 \mu$ m. The cell phenotype at the third passage was $\mathrm{CD} 31^{+} \mathrm{CD} 34^{+} \mathrm{Flk}-1^{+} \mathrm{CD} 45^{-} \mathrm{CD} 133^{-}$(E). The expression of GFP in EPCs was detected at day 7 after BMP2-eGFP transduction by inverted microscopy (F) and fluorescence microscopy (G, green fluorescence $>90 \%$ ), overlaying to result in micrograph $(H)$, Bar $=100 \mu \mathrm{m}$.

Fig. 2. Degrees of lung injury. The sham group showed no obvious injury (A), while injury degrees assessed by alveolar congestion, hemorrhage, infiltration of inflammatory cells, and thickness of the alveolar wall were significantly improved in the lung tissues treated with EPCs (C), EPCs-null (D), and EPCs-BMP2 (E) compared with the saline-treated injury group (B), Bar $=100 \mu \mathrm{m}$, consistent with the injury score (F). Data are presented as mean $\pm \mathrm{SD}, \mathrm{n}=8$. ${ }^{\# \#} \mathrm{P}<0.01$ versus the sham group, ${ }^{* *} \mathrm{P}<0.01$ versus the saline-treated injury group.

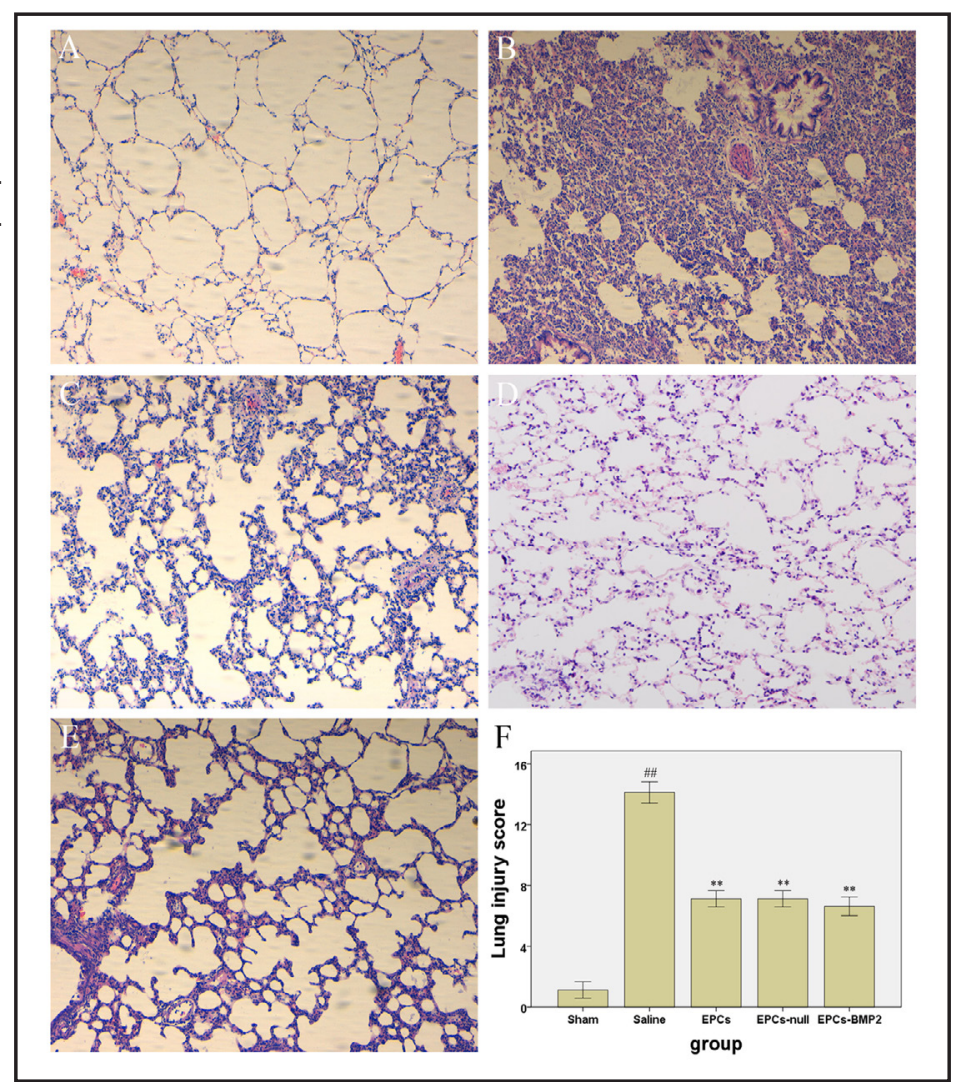



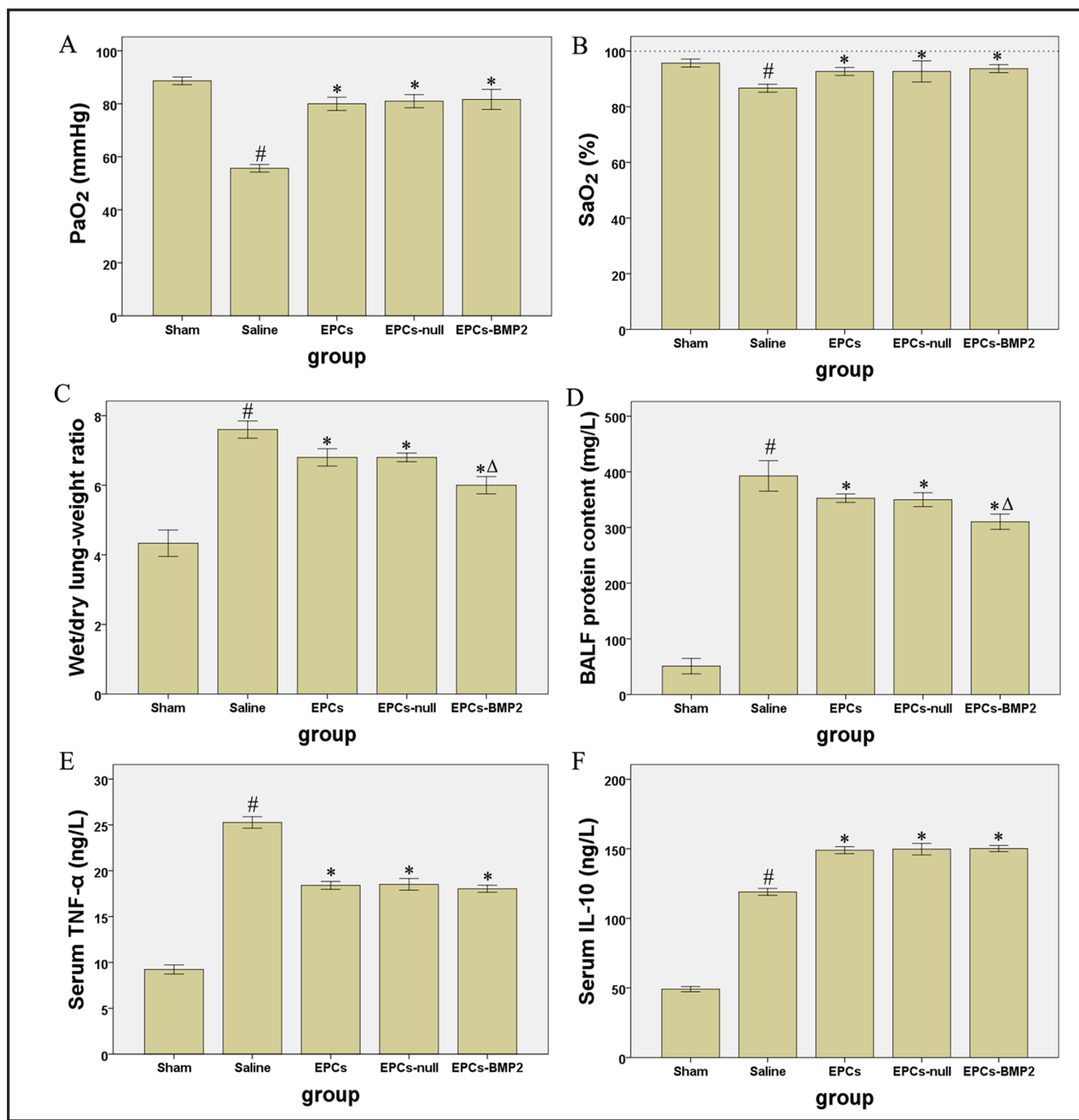

Fig. 3. Improvement of lung oxygenation, edema, protein exudation, and inflammation. $\mathrm{PaO} 2(\mathrm{~A}), \mathrm{SaO} 2(\mathrm{~B})$, wet-to-dry lung-weight ratio (C), BALF protein content (D), serum levels of TNF- $\alpha$ (E), and IL-10 (F) were illustrated. Data are presented as mean $\pm S D, n=8$. ${ }^{*} \mathrm{P}<0.05$ versus the sham group, ${ }^{*} \mathrm{P}<0.05$ versus the salinetreated injury group, ${ }^{\triangle} \mathrm{P}<0.05$ versus the EPCs and EPCs-null groups.

Compared with the sham group, LPS caused significant increases in the wet-to-dry lungweight ratio, BALF protein content, and PMN counts $(\mathrm{P}<0.05)$. Transplantation of EPCs, EPCs-null, and EPCs-BMP2 significantly attenuated these increases, particularly in terms of wet-to-dry lung-weight ratio and BALF protein content in the EPCs-BMP2 group compared with the EPCs and EPCs-null groups $(\mathrm{P}<0.05$, Figs. 3C, D).

Serum levels of TNF- $\alpha$ and $I L-10$

Serum levels of TNF- $\alpha$ and IL-10 were significantly increased after LPS injection in rats $(\mathrm{P}<0.05)$. Compared with the injury group treated with saline, serum levels of the proinflammatory cytokine TNF- $\alpha$ were significantly inhibited and levels of the anti-inflammatory cytokine IL-10 were significantly enhanced in rats treated with EPCs, EPCs-null, and EPCsBMP2 ( $<<0.05$, Figs. 3E, F). 


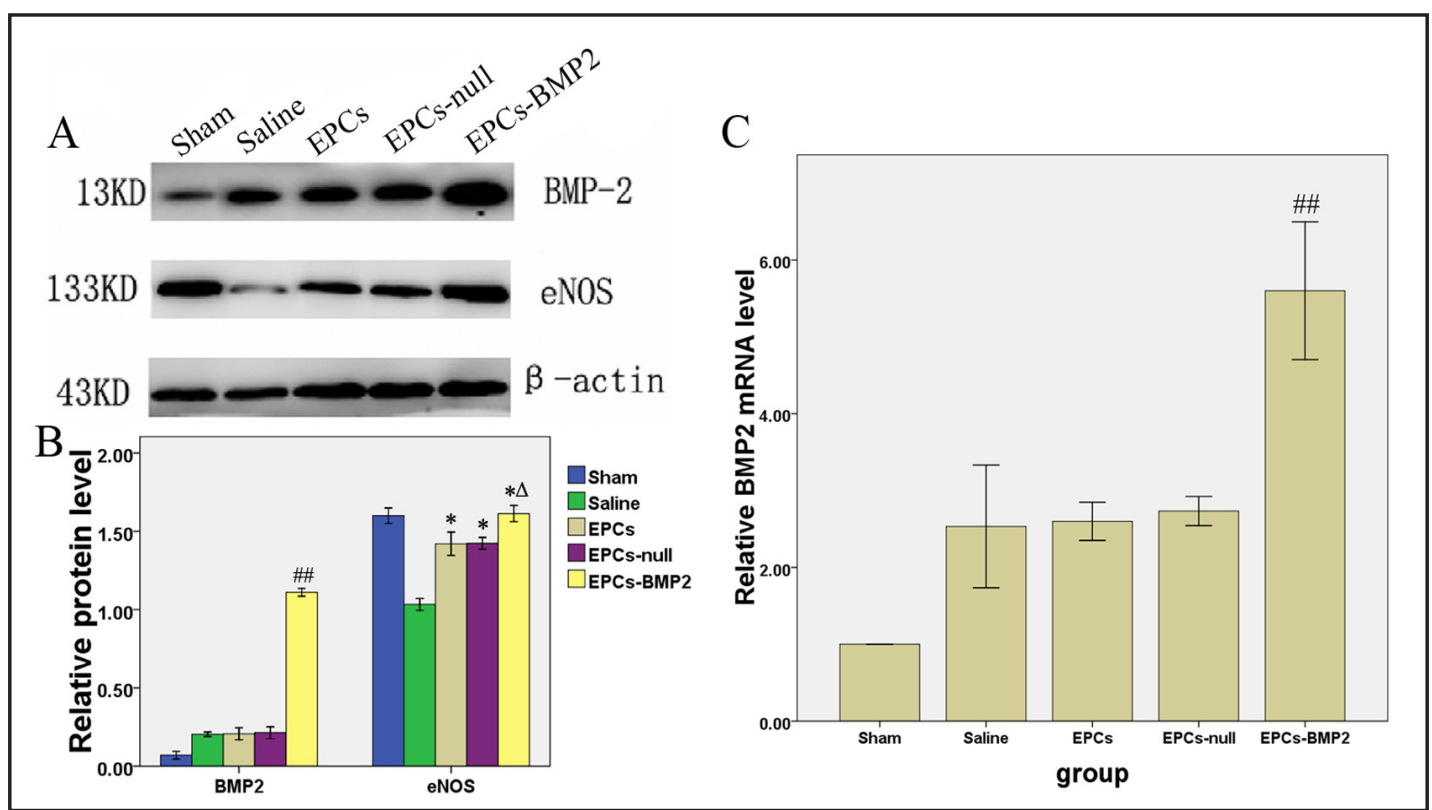

Fig. 4. Expression of BMP 2 and eNOS proteins (A, B) and BMP 2 mRNA (C) in lung tissues. Data are presented as mean $\pm \mathrm{SD}, \mathrm{n}=8$. ${ }^{\# \#} \mathrm{P}<0.01$ versus the other groups, ${ }^{*} \mathrm{P}<0.05$ versus the saline-treated injury group, ${ }^{\Delta} \mathrm{P}<0.05$ versus the EPCs and EPCs-null groups.

Expression of BMP2 and eNOS proteins and BMP2 $m R N A$ in lung tissues

BMP2 protein and mRNA levels were significantly increased in lung tissues following EPCs-BMP2 administration, compared with the other groups $(\mathrm{P}<0.01$, Figs. $4 \mathrm{~A}-\mathrm{C})$. In the lung injury groups, eNOS protein expression was considerably up-regulated in rat lung after cell transplantation, among which EPCs-BMP2 significantly enhance the expression than EPCs and EPCs-null $(\mathrm{P}<0.05$, Fig. 4B).

\section{Discussion}

Our study demonstrated that transplantation of BMP2-transduced bone marrowderived EPCs could reduce the wet-to-dry lung-weight ratio, BALF protein content, and regulate the inflammatory cytokines TNF- $\alpha$ and IL-10, thereby attenuating the pathological damage and improving oxygenation in rats with LPS-induced ALI. Moreover, the wet-to-dry lung-weight ratio and BALF protein content were significantly reduced by transplantation of EPCs-BMP2 compared with EPCs alone, indicating the ability of BMP2 gene transfer to decrease lung edema and vascular permeability via up-regulating the expression of BMP2 and eNOS.

In the early exudative phase, endothelial cells play a vital role in maintaining the integrity of the alveolar-capillary barrier during the initiation and progression of ALI/ARDS [25]. Endothelial injury causes vascular disruption and hyperpermeability, accompanied by proteinaceous fluid extravasation. Endothelium-targeted therapeutic strategies utilizing EPCs have been shown to restore the endothelial barrier and inhibit inflammatory damage in lung injury [26]. Among EPC subpopulations, so-called "late EPCs", which have a cobblestone shape, long lifespan, and are negative for the surface markers CD133 and CD45 [27], produce more nitric oxide and show better tube formation [28]. In view of the profound endothelial healing and angiogenic properties [29], we chose late EPCs for gene transfer and transplantation in our study.

BMP2 is a multifunctional signaling protein that regulates the behavior of both stem and endothelial cells [30]. We used a lentiviral vector to mediate BMP2 gene transfer to 


\section{Cellular Physiology Cell Physiol Biochem 2015;35:2149-2158 \begin{tabular}{l|l} 
Dol: 10.1159/000374020 & $\begin{array}{l}\text { 2015 s. Karger AG, Basel } \\
\text { www.karger.com/cpb }\end{array}$ \\
\hline
\end{tabular}

achieve high and stable long-term transgene expression without stimulating an immune response [31]. Consistent with the effectiveness of EPCs shown in other studies[4-8], BMP2transduced EPCs minimized LPS-induced ALI in rats in terms of pathological changes, arterial oxygen content, wet-to-dry lung-weight ratio, BALF protein content, and expression of the inflammatory cytokines TNF- $\alpha$ and IL-10. The endothelial-repair effect of BMP2transduced EPCs was particularly noticeable in relation to wet-to-dry lung-weight ratio and BALF protein content, indicating improved microvascular permeability and barrier integrity. Therefore, the BMP2 genetically-modified late EPCs can be proved to have a dual enhancing effect on maintaining the integrity of injured endothelium in ALI.

Regarding the possible mechanisms, we confirmed the enhanced expression levels of BMP2 protein in lung tissues after transplantation. It has been shown that BMP2 treatment activates EPCs chemotaxis in a dose-dependent manner[20], and protects against apoptosis in pulmonary artery endothelial cells [21]. In this study, we found that besides the direct repair role by EPCs and BMP2, the increased expression of eNOS protein secondary to the relatively intact endothelium and being the target of BMP2 signaling [32, 33] could also act. As we known, eNOS is fundamental to endothelial cells in keeping their normal functions through the regulation EPC mobilization [34] and microvascular permeability [35]. Hence, the benefits of BMP2-transduced EPCs in repairing the injured endothelium may be attributed to the above synergistic effects.

There were some limitations associated with the present study design. Firstly, we did not observe the vascular wall ultrastructure directly, and only analyzed the results at single time point after cell transplantation. Secondly, the LPS-induced ALI rat model does not completely reflect the inflammatory condition in humans, and it was difficult to obtain enough genetically-transduced EPCs for transplantation before the occurrence of ALI. Further studies are therefore needed to clarify the exact mechanisms and clinical applications.

In conclusion, in addition to the beneficial effects of EPCs alone on oxygenation, pathological changes, and inflammatory response, BMP2-transduced EPCs may further attenuate LPS-induced acute lung injury in rats by improving endothelium repair in terms of reduced wet-to-dry lung-weight ratio and BALF protein content via enhanced expression of BMP2 and eNOS.

\section{Disclosure Statement}

The authors declare no conflict of interest.

\section{Acknowledgments}

This study was supported by a program grant from the Natural Science Foundation of China (Grant number: 81071530).

\section{References}

1 Frutos-Vivar F, Nin N, Esteban A: Epidemiology of acute lung injury and acute respiratory distress syndrome. Curr Opin Crit Care 2004;10:1-6.

2 Ware LB, Matthay MA: The acute respiratory distress syndrome. N Engl J Med 2000;342:1334-1349.

3 Asahara T, Murohara T, Sullivan A, Silver M, van der Zee R, Li T, Witzenbichler B, Schatteman G, Isner JM: Isolation of putative progenitor endothelial cells for angiogenesis. Science 1997;275:964-967.

$4 \quad$ Lam CF, Liu YC, Hsu JK, Yeh PA, Su TY, Huang CC, Lin MW, Wu PC, Chang PJ, Tsai YC: Autologous transplantation of endothelial progenitor cells attenuates acute lung injury in rabbits. Anesthesiology 2008;108:392-401. 


\section{Cellular Physiology Cell Physiol Biochem 2015;35:2149-2158

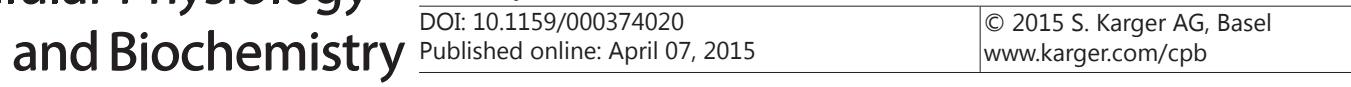

5 Mao M, Wang SN, Lv XJ, Wang Y, Xu JC: Intravenous delivery of bone marrow-derived endothelial progenitor cells improves survival and attenuates lipopolysaccharide-induced lung injury in rats. Shock 2010;34:196204.

6 Lam CF, Roan JN, Lee CH, Chang PJ, Huang CC, Liu YC, Jiang MJ, Tsai YC: Transplantation of endothelial progenitor cells improves pulmonary endothelial function and gas exchange in rabbits with endotoxininduced acute lung injury. Anesth Analg 2011;112:620-627.

7 Cao JP, He XY, Xu HT, Zou Z, Shi XY: Autologous transplantation of peripheral blood-derived circulating endothelial progenitor cells attenuates endotoxin-induced acute lung injury in rabbits by direct endothelial repair and indirect immunomodulation. Anesthesiology 2012;116:1278-1287.

8 Gao X, Chen W, Liang Z, Chen L: Autotransplantation of circulating endothelial progenitor cells protects against lipopolysaccharide-induced acute lung injury in rabbit. Int Immunopharmacol 2011;11:1584-1590.

9 Rabelink TJ, de Boer HC, de Koning EJ, van Zonneveld AJ: Endothelial progenitor cells: More than an inflammatory response? Arterioscler Thromb Vasc Biol 2004;24:834-838.

10 Zhang Y, Ingram DA, Murphy MP, Saadatzadeh MR, Mead LE, Prater DN, Rehman J: Release of proinflammatory mediators and expression of proinflammatory adhesion molecules by endothelial progenitor cells. Am J Physiol Heart Circ Physiol 2009;296:H1675-1682.

11 Hur J, Yoon CH, Lee CS, Kim TY, Oh IY, Park KW, Kim JH, Lee HS, Kang HJ, Chae IH, Oh BH, Park YB, Kim HS: Akt is a key modulator of endothelial progenitor cell trafficking in ischemic muscle. Stem Cells 2007;25:1769-1778.

12 Iwaguro H, Yamaguchi J, Kalka C, Murasawa S, Masuda H, Hayashi S, Silver M, Li T, Isner JM, Asahara T: Endothelial progenitor cell vascular endothelial growth factor gene transfer for vascular regeneration. Circulation 2002;105:732-738.

13 Park SJ, Baek SH, Oh MK, Choi SH, Park EH, Kim NH, Shin JC, Kim IS: Enhancement of angiogenic and vasculogenic potential of endothelial progenitor cells by haptoglobin. FEBS Lett 2009;583:3235-3240.

14 Kuliszewski MA, Kobulnik J, Lindner JR, Stewart DJ, Leong-Poi H: Vascular gene transfer of SDF-1 promotes endothelial progenitor cell engraftment and enhances angiogenesis in ischemic muscle. Mol Ther 2011;19:895-902.

15 Chen L, Wu F, Xia WH, Zhang YY, Xu SY, Cheng F, Liu X, Zhang XY, Wang SM, Tao J: CXCR4 gene transfer contributes to in vivo reendothelialization capacity of endothelial progenitor cells. Cardiovasc Res 2010;88:462-470.

16 Song MB, Yu XJ, Zhu GX, Chen JF, Zhao G, Huang L: Transfection of hgf gene enhances endothelial progenitor cell $(\mathrm{epc}$ ) function and improves epc transplant efficiency for balloon-induced arterial injury in hypercholesterolemic rats. Vascul Pharmacol 2009;51:205-213.

17 Zhao Q Liu Z, Wang Z, Yang C, Liu J, Lu J: Effect of prepro-calcitonin gene-related peptide-expressing endothelial progenitor cells on pulmonary hypertension. Ann Thorac Surg 2007;84:544-552.

18 Nagaya N, Kangawa K, Kanda M, Uematsu M, Horio T, Fukuyama N, Hino J, Harada-Shiba M, Okumura H, Tabata Y, Mochizuki N, Chiba Y, Nishioka K, Miyatake K, Asahara T, Hara H, Mori H: Hybrid cell-gene therapy for pulmonary hypertension based on phagocytosing action of endothelial progenitor cells. Circulation 2003;108:889-895.

19 Belmokhtar K, Bourguignon T, Worou ME, Khamis G, Bonnet P, Domenech J, Eder V: Regeneration of three layers vascular wall by using BMP2-treated MSC involving HIF-1 $\alpha$ and Id1 expressions through JAK/STAT pathways. Stem Cell Rev 2011;7:847-859.

20 Raida M, Heymann AC, Gunther C, Niederwieser D: Role of bone morphogenetic protein 2 in the crosstalk between endothelial progenitor cells and mesenchymal stem cells. Int J Mol Med 2006;18:735-739.

21 Teichert-Kuliszewska K, Kutryk MJ, Kuliszewski MA, Karoubi G, Courtman DW, Zucco L, Granton J, Stewart DJ: Bone morphogenetic protein receptor-2 signaling promotes pulmonary arterial endothelial cell survival: Implications for loss-of-function mutations in the pathogenesis of pulmonary hypertension. Circ Res 2006;98:209-217.

22 Burton VJ, Ciuclan LI, Holmes AM, Rodman DM, Walker C, Budd DC: Bone morphogenetic protein receptor II regulates pulmonary artery endothelial cell barrier function. Blood 2011;117:333-341.

23 Li H, Qiang Y, Wang L, Wang G, Yi J, Jing H, Wu H: Repair of lipopolysaccharide-induced acute lung injury in mice by endothelial progenitor cells, alone and in combination with simvastatin. Chest 2013;144:876-886

24 Fadini GP, Agostini C, Avogaro A: Characterization of endothelial progenitor cells. Biochem Biophys Res Commun 2005;336:1-2. 


\section{Cellular Physiology Cell Physiol Biochem 2015;35:2149-2158 \begin{tabular}{ll|l} 
and Bioch $10.1159 / 000374020$ & $\begin{array}{l}\text { O 2015 S. Karger AG, Basel } \\
\text { www.karger.com/cpb }\end{array}$ \\
\hline
\end{tabular}

25 Tomashefski JF, Jr.: Pulmonary pathology of acute respiratory distress syndrome. Clin Chest Med 2000;21:435-466.

26 Yamada M, Kubo H, Kobayashi S, Ishizawa K, Numasaki M, Ueda S, Suzuki T, Sasaki H: Bone marrow-derived progenitor cells are important for lung repair after lipopolysaccharide-induced lung injury. J Immunol 2004;172:1266-1272.

27 Timmermans F, Van Hauwermeiren F, De Smedt M, Raedt R, Plasschaert F, De Buyzere ML, Gillebert TC, Plum J, Vandekerckhove B: Endothelial outgrowth cells are not derived from CD133+ cells or CD45+ hematopoietic precursors. Arterioscler Thromb Vasc Biol 2007;27:1572-1579.

28 Hur J, Yoon CH, Kim HS, Choi JH, Kang HJ, Hwang KK, Oh BH, Lee MM, Park YB: Characterization of two types of endothelial progenitor cells and their different contributions to neovasculogenesis. Arterioscler Thromb Vasc Biol 2004;24:288-293.

29 Zampetaki A, Kirton JP, Xu Q: Vascular repair by endothelial progenitor cells. Cardiovasc Res 2008;78:413421.

30 ten Dijke P, Korchynskyi O, Valdimarsdottir G, Goumans MJ: Controlling cell fate by bone morphogenetic protein receptors. Mol Cell Endocrinol 2003;211:105-113.

31 Picanco-Castro V, de Sousa Russo-Carbolante EM, Tadeu Covas D: Advances in lentiviral vectors: a patent review. Recent Pat DNA Gene Seq 2012;6:82-90.

32 Gangopahyay A, Oran M, Bauer EM, Wertz JW, Comhair SA, Erzurum SC, Bauer PM: Bone morphogenetic protein receptor II is a novel mediator of endothelial nitric-oxide synthase activation. J Biol Chem 2011;286:33134-33140.

33 Anderson L, Lowery JW, Frank DB, Novitskaya T, Jones M, Mortlock DP, Chandler RL, de Caestecker MP: Bmp2 and Bmp4 exert opposing effects in hypoxic pulmonary hypertension. Am J Physiol Regul Integr Comp Physiol 2010;298:R833-842.

34 Aicher A, Heeschen C, Mildner-Rihm C, Urbich C, Ihling C, Technau-Ihling K, Zeiher AM, Dimmeler S: Essential role of endothelial nitric oxide synthase for mobilization of stem and progenitor cells. Nat Med 2003;9:1370-1376.

35 Hatakeyama T, Pappas PJ, Hobson RW, 2nd, Boric MP, Sessa WC, Duran WN: Endothelial nitric oxide synthase regulates microvascular hyperpermeability in vivo. J Physiol 2006;574:275-281. 